\title{
ACCOUNTING AND TAX KNOWLEDGE BAGI USAHA KECIL DAN MENENGAH SUB SEKTOR JASA
}

\section{ACCOUNTING AND TAX KNOWLEDGE FOR SMALL AND MEDIUM ENTERPRISES SERVICES SECTOR}

\author{
${ }^{1)}$ Gunasti, ${ }^{2}$ Supriyati \\ ${ }^{1,2)}$ Fakultas Ekonomi, STIE Perbanas Surabaya \\ Jl. Nginden Semolo 34 Surabaya \\ astit@perbanas.ac.id \\ supriyati@perbanas.ac.id
}

\begin{abstract}
ABSTRAK
Usaha foto copy saat ini telah mengalami perkembangan yang pesat. Namun demikian, pemilik dan pengelola usaha foto copy belum dapat menunjukkan tingkat perkembangan usaha mereka karena ketiadaan pencatatan usaha mereka. Masalah pencatatan akuntansi selama ini masih merupakan masalah klasik karena latar belakang pendidikan dan pengetahuan mereka. Kegiatan pengabdian masyarakat ini bertujuan untuk membantu usaha kecil dan menengah bidang usaha foto copy dalam penyelenggaraan pencatatan dan pelaporan akuntansi dan pajak agar terwujud kelangsungan usahanya dan memiliki daya saing di masa datang. Kegiatan pengabdian masyarakat ini diprioritaskan membantu mengatasi permasalahan ini agar usaha foto copy yang juga termasuk usaha kecil dan menengah ini memiliki daya saing dan mampu mengembangkan usaha di masa datang. Kegiatan pengabdian masyarakat yang dilakukan meliputi pelatihan dan advokasi kepada mitra. Pelatihan diarahkan pada penyusunan pencatatan dan pelaporan akuntansi dan pajak secara sederhana pada mitra. Advokasi berupa pendampingan kepada mitra yang berupa pencatatan dan pelaporan akuntansi dan pajak sederhana bagi usaha kecil menengah dengan menggunakan software aplikasi akuntansi dan pajak sederhana yang telah disusun bersama tim pelaksana.Hasil kegiatan pengabdian masyarakat berupa tersusunnya software aplikasi akuntansi dan pajak sederhana. Juga, adanya peningkatan pemahaman ketrampilan pemilik yang sebelumnya tidak mengetahui pencatatan akuntansi dan pajak, sekarang mereka mampu menyusun pelaporan akuntansi dan pajak secara terstruktur.
\end{abstract}

Kata kunci : Pelatihan, Pendampingan, Pelaporan Akuntansi, Perpajakan

\section{ABSTRACT}

The current copy business has experienced rapid development. However, the owners and managers of the copy business have not been able to show the level of development of their business due to the absence of recording their business. The problem of accounting records so far is still a classic problem because of their educational background and knowledge. This community service activity aims to help small and medium enterprises in the field of photocopy business in the administration of accounting and tax reporting in order to realize their business continuity and have competitiveness in the future. This community service activity is prioritized to help overcome this problem so that the photocopy business, which also includes small and medium enterprises, has the competitiveness and is able to develop business in the future. Community service activities carried out include training and advocacy for partners. Training is directed at the preparation of simple accounting and tax recording and reporting on partners. Advocacy in the form of assistance to partners in the form of simple accounting and tax recording and reporting for small and medium enterprises by using simple accounting and tax application software that has been compiled with the implementation team. The results of community service activities are in the form of simple accounting and tax application software. Also, there is an increased understanding of the skills of owners who previously did not know accounting and tax records, now they are able to arrange accounting and tax reporting in a structured manner

Keywords : Training, Assistance, Accounting Reporting, Taxation 
Accounting And Tax Knowledge Bagi Usaha Kecil Dan Menengah Sub Sektor Jasa

Submited : 21 Juni $2018 \quad$ Revision : 13 Desember 2018 Accepted : 26 Desember 2018

\section{PENDAHULUAN}

Dalam pembangunan ekonomi kerakyatan, UMKM mempunyai peranan yang penting dan strategis untuk mewujudkan struktur dunia usaha nasional yang kokoh. Sehubungan dengan hal tersebut maka UMKM perlu ditingkatkan jumlahnya dan diberdayakan menjadi usaha yang tangguh, mandiri dan unggul, sehingga peranannya dalam penyerapan tenaga kerja, ekspor dan pembentukan produk domestik bruto semakin meningkat. Undang-Undang Republik Indonesia Nomor 20 Tahun 2008 Tentang Usaha Mikro, Kecil Dan Menengah dinyatakan bahwa Kriteria Usaha Mikro, Kecil dan Menengah (UMKM).

Penggunaan informasi akuntansi dalam pengambilan keputusan akan mempengaruhi prestasi perusahaan, khususnya bagi UMKM. Dengan dimanfaatkannya informasi akuntansi dalam pengambilan keputusan investasi maka akan mendukung ketepatan wirausaha dalam mempertimbangkan konsekuensi keuangan atas keputusan yang diambil. Pembukuan dan pelaporan keuangan merupakan hal yang cukup penting dalam pertumbuhan dan perkembangan usahanya (Jati Hironnymus, 2004).

Dalam hubungannya antara UMKM dengan pemerintah dan kreditur (Bank), penyediaan informasi akuntansi oleh UMKM juga sangat diperlukan. Karena salah satu teknik pemberian kredit yang paling banyak digunakan bank adalah financial statement lendingyang mendasarkan pemberian kreditnya atas informasi keuangan dari debiturnya. Pihak bank tidak melihat adanya perbedaan antara usaha besar dengan UMKM, semuanya diwajibkan untuk memenuhi persyaratan termasuk harus menyediakan laporan keuangan untuk dapat dijadikan dasar dalam memberikan pinjaman kepada calon debitor(Fess, 2017).

Namun di sisi lain hal tersebut menjadi kendala tersendiri sebab UMKM ternyata tidak mampu menyediakan informasi keuangan yang diperlukan oleh bank tersebut. Jika melihat persyaratan pemberian kredit pada hampir semua bank di Indonesia menunjukkan bahwa informasi keuangan diperlukan untuk meyakinkan kelancaran pembayaran angsuran dan pengembalian pinjaman oleh calon debitur, sebagai pertimbangan karakter calon debitur. Juga, laporan keuangan yang menggambarkan pendapatan dan beban usaha serta aset, kewajiban dan modal yang dimiliki calon debitur menjadi pertimbangan utama keputusan diterima tidaknya permohonan kredit oleh Bank, tidak terkecuali bagi UMKM. Untuk itu, dapat dikatakan bahwa praktik akuntansi sangat terkait dengan akses terhadap kredit UMKM, dengan praktik akuntansi yang memadai maka akan memudahkan pelaku UMKM untuk memberikan keyakinan kepada bank atau calon kreditur bahwa usaha dapat dijalankan dan dibiayai (Feasible), pelaku UMKM dapat memenuhi persyaratan kredit/pembiayaan (Bankable), dana yang diberikan dapat dipertanggungjawabkan (Accountable) dan usaha yang dijalankan dapat menguntungkan (Profitable). Pemahaman SAK-ETAP masih rendah dan sebagian besar dipengaruhi oleh pendidikan, jenis usaha, jumlah SDM (Supriyati \& Wulanditya, 2012).

Usaha Kecil Menengah di Surabaya, khususnya di sekitar kampus STIE Perbanas Surabaya, berkembang sangat cepat. Hal ini didukung dengan adanya beberapa kampus yang sangat terkait dengan kebutuhan mahasiswa. Usaha foto copy disekitar kampus sangat membantu mahasiswa perguruan tinggi disekitarnya. Bagi mahasiswa, maupun perguruan tinggi sendiri, kebutuhan foto 
copy dan printing di sekitar kampus sangat menunjang kelancaran tugas-tugas perkuliahan dan membantu percepatan dalam pemenuhan administrasi khususnya terkait dengan penggandaan laporanlaporan.

Di dalam aspek perpajakan juga muncul aturan baru terkait dengan usaha kecil dan menengah yang diatur dalam Peraturan Pemerintah Republik Indonesia Nomor 46 Tahun 2013 yang berlaku efektif mulai 1 Juli 2013. PP 46 tahun 2013 tersebut memberlakukan sebagai berikut:(a) PPh Final untuk pajak UKM adalah pajak atas penghasilan dari usaha yang diterima atau diperoleh WajibPajak yang memiliki peredaran bruto atau omzet di bawah Rp 4,8 miliar dalam setahun dansemua transaksi penjualan dikenakan tarif $1 \%$, (b) dasar pengenaan pajak yang digunakan untuk menghitung pajak penghasilan yang bersifat final adalah jumlah peredaran bruto setiap bulan(RI, 2013).

Dalam operasionalnya, usaha foto copy tidak terlepas dari ketepatan dalam penyediaan kertas foto copy. Efisiensi penggunaan kertas sangat membantu dalam peningkatan kinerjanya. Saat ini diketahui bahwa harga kertas foto copy terus meningkat. Di sisi lain risiko terhadap hilang dan rusaknya atau pemborosan kertas tidak pernah diukur, dievaluasi dan dimonitor. Lebih lanjut semuanya akan berdampak menjadi lemahnya dalam persaingan usaha. Diketahui dari luaran tugas Akuntansi Pengantar 2 periode gasal 2017/2018 pada usaha foto copy Rapopo milik perorangan Bp. Andik Kiswanto, dan usaha foto copy Sinar Terang milik bu Isroh yang beralamat di jalan Nginden Semolo 38 Surabaya, Usaha tersebut telah berdiri lebih dari 11 tahun dan memiliki lebih dari 3(tiga) tempat usaha. Selama ini pencatatan telah dilakukan namun sangat sederhana dengan manual sehingga pelaporan keuangan yang dihasilkan masih terbatas. Monitoring terhadap 1(satu) bulan transaksi menunjukkan perolehan data yang sangat terbatas sehingga hasil akhir untuk mengukur kinerja usaha tersebut menjadi terbatas. Hal yang sama pada usaha foto copy Sinar Terang yang juga sudah memiliki beberapa tempat usaha. Sampai dengan saat ini belum pernah dihasilkan pelaporan keuangan usaha.

Adanya Standar Akuntansi Keuangan EMKM (Entitas Mikro, Kecil, dan Menengah) yang sudah diberlakukan Januari 2018 ini, dan kewajiban pelaporan SPT PPh Orang Pribadi, menjadikan EMKM seperti usaha jasa fotocopy wajib menyusun laporan keuangan(IAI, 2016). Terbatasnya personil pada EMKM ini dalam penyusunan laporan keuangan dan perhitungan pajak, sudah saatnya dibutuhkan penggunaan software seperti pelaporan akuntansi berbasis excelsederhana untuk percepatan dan ketepatan penyusunan laporan keuangan dan perpajakan. Karena itu, tujuan kegiatan pengabdian masyarakat ini adalah meningkatkan pemahaman dan ketrampilan pemilik usaha kecil dan menengah serta menyusun software aplikasi sederhana pelaporan akuntansi dan pajak

\section{METODE}

Metode pelaksanaan yang telah dilakukan oleh tim pelaksana selama masa pengabdian masyarakat meliputi tahap pertama adalah tahap persiapanini dimulai dari rapat koordinasi yang dilakukan oleh tim pelaksana bersama pemilik usaha kecil dan menengah. Tahap kedua adalah tahap pelaksanaan yang meliputi: (a) pelatihan pencatatan dan pelaporan akuntansi dan pajak; (b) advokasi kepada mitra.

Kegiatan pelatihan dilakukan kampus STIE Perbanas Surabaya dengan target peserta sebanyak 10 orang yang berada disekitar Surabaya. Peserta diberikan wawasan singkat tentang proses pencatatan dan pelaporan akuntansi serta perhitungan pajak secara sederhana. Peserta selanjutnya diberikan latihan dan 
praktik pencatatan dan penyusunan laporan keuangan dan pajak berdasarkan kasus transaksi selama sebulan. Pelatihan ini dilakukan secara manual dengan menggunakan kertas kerja.

Kegiatan selanjutnya adalah advokasi kepada mitra bersama tim mahasiswa. Pendampingan mitra ini berupa pendampingan pencatatan transaksi rutin, pembuatan modul untuk memudahkan proses belajar mitra, dan penyusunan pelaporan akuntansi dan pajak. Target di tahap pelaksanaan ini adalah usaha kecil dan menengah mampu mengoperasionalkan pencatatan akuntansi dan pajak berbasis excel.

\section{HASIL DAN PEMBAHASAN}

Usaha jasa foto copy yang telah dilakukan oleh kedua pemilik yang menjadi mitra kegiatan pengabdian masyarakat ini telah dijalankan cukup lama. UD. Rapopo telah berdiri empat tahun lalu dan UD Sinar Terang telah berdiri hampir lima belas tahun. Kedua UKM menjalankan usaha tanpa memiliki pegawai dibagian akuntansi atau pembukuan. Selama ini keduanya belum memiliki pencatatan akuntansi yang sempurna. Kedua UKM hanya mencatat penghasilan yang diperoleh setiap harinya. Kondisi ini berdampak pada aspek pelaporan yang berkaitan dengan pelaporan akuntansi dan pajak. Adapun langkahlangkah pengabdian masyarakat yang dilakukan tim pelaksana yaitu:

1. Tahap awal yang dilakukan adalah identifikasi permasalahan dan alternatif solusi atas permasalahan tersebut.

Tim pelaksana melakukan wawancara secara rutin dengan dibantu tiga orang mahasiswa jurusan Akuntansi STIE Perbanas guna mengindentifikasi transaksi dan pelaporan yang akan dibuatkan software aplikasinya. Hasil yang diperoleh menunjukkan bahwa kedua mitra belum memiliki pencatatan secara baik.Transaksi bisnis mereka masih belum terpisah dengan keuangan pribadi, transaksi bisnis foto copy belum terpisah dengan usaha rental komputer, pemilik belum memiliki pemahaman tentang manfaat bila menyusun pelaporan akuntansi.

2. Tahap pelaksanaan berupa ditujukan bagi pemilik atau pengelola usaha foto copy baik bagi mitra pengabdian ini maupun pemilik usaha foto copy lain yang bersedia mengikuti kegiatan pelatihan ini.

Hasil pelatihan ini menunjukkan bahwa (a) pemilik dan pengelola cukup memahami transaksi bisnis tetapi belum terbiasa melakukan pencatatan, (b) selama ini usaha yang dijalankan bersumber dari modal sendiri dan belum memerlukan permodalan dari pihak luar sehingga mereka belum merasa kebutuhan akan pelaporan akuntansi, (c) pemahaman aspek perpajakan sangat rendah sehingga selama ini untuk pembayaran dan pelaporan pajak dibantu oleh konsultan pajak atau orang lain, (d) omzet usaha foto copy ini tergolong meningkat tetapi mereka belum melakukan kewajiban perpajakannya secara benar menurut ketentuan perundang-undangan perpajakan bahkan ada yang tidak membayar walaupun sudah memperoleh surat peringatan. Adanya pelatihan ini sangat memberikan pengetahuan dan wawasan baru terkait dengan pencatatan dan pelaporan baik akuntansi maupun perpajakan. Karena itu, pemilik dan pengelola usaha foto copy berharap dapat diberikan bantuan berupa software aplikasi akuntansi dan perpajakan yang sederhana sehingga mempermudah operasional mereka.

3. Tahap pelaksanaan berupa penyusunan software aplikasi akuntansi dan perpajakan yang sederhana berbasis excel 
Tim pelaksana awalnya menyusun modul pencatatan dan pelaporan akuntansi dan perpajakan bagi usaha kecil menengah di bidang usaha foto copyterlebih dahulu. Modul tersebut terdiri dari 3 bagian, yaitu bagian 1 tentang akuntansi sederhana bagi UKM, bagian 2 tentang perhitungan pajak penghasilan bagi UKM yang memiliki usaha, bagian 3 tentang praktik pencatatan dan pelaporan akuntansi dan pajak sederhana. Sedangkan software aplikasi akuntansi dan perpajakan didisain dalam beberapa sheet yang meliputi lembar kerja, kode akun, kode bantu, jurnal umum, buku besar, buku pembantu, neraca lajur, laba rugi, neraca. Juga disediakan fasilitas print untuk jurnal umum, buku besar, buku pembantu, kode akun, kode akun pembantu, neraca lajur, laba rugi dan neraca. Praktik kasus yang dijadikan contoh untuk penyelesaian software aplikasi akuntansi dan pajak sederhana ini adalah transaksi bisnis selama bulan Mei 2018 berdasarkan wawancara dan survey yang dilakukan oleh tim mahasiswa dalam tahap awal.

4. Tahap akhir pelaksanaan adalah melakukan pendampingan pada pemilik dan pengelola usaha foto copy kedua mitra.

Pendampingan yang dilakukan mulai dari proses pencatatan transaksi bisnis, mekanisme pengoperasian software aplikasi akuntansi dan pajak sederhana, proses penyusunan pelaporan akuntansi serta perhitungan pajak penghasilan sesuai norma penghitungan pajak penghasilan dengan tarif pajak $1 \%$ atas dasar omzet. Hasil pendampingan ini menunjukkan bahwa (a) pemilik sudah memiliki pemahaman akuntansi dan pajak secara sederhana, (b) pemilik dengan cepat mampu mengoperasikan software aplikasi akuntansi dan pajak sederhana karena saat pemilik melakukan entri transaksi langsung dapat diketahui pelaporannya tanpa berpikir lagi, (c) software ini masih perlu dipertimbangkan pengembangannya ketika nanti omzet usaha foto copy ini meningkat ataupun ketika unit bisnis usaha mereka mulai beraneka ragam.

Rendahnya pengetahuan yang dimiliki pemilik usaha kecil dan menengah karena dipengaruhi oleh berbagai faktor. Penelitian yang dilakukan Supriyati \& Wulanditya (2012) menunjukkan tingkat pendidikan, pengalaman kerja dan motivasi memiliki pengaruh terhadap kepatuhan wajib pajak. Pemilik usaha kecil dan menengah sebagian memiliki tingkat pendidikan yang masih rendah, dan jarang menerima berbagai pelatihan terkait dengan akuntansi dan pajak. Hal ini yang membuat mereka belum mengaplikasi pencatatan akuntansi dan pelaporan pajak secara tepat dan benar.

Berbagai kegiatan pengabdian masyarakat yang dilakukan pada mitra memberikan manfaat bagi mereka dalam peningkatan pengetahuan dan wawasan tentang pentingnya pencatatan dan pelaporan akuntansi dan pajak dalam operasional mereka. Banyaknya tuntutan dan kewajiban yang harus dipenuhi khususnya kewajiban perpajakan harus dapat dipahami oleh mereka dan juga dampak yang akan ditanggung ketika mereka tidak melakukan kewajiban perpajakannya. Namun demikian, ada beberapa kendala yang harus dipertimbangkan bagi akademisi lain yaitu terkait dengan tingkat pendidikan, usia pemilik dan pengelola, tingkat omzet yang diperoleh dan bidang usaha.

\section{SIMPULAN}

Usaha kecil dan menengah termasuk usaha foto copy saat ini telah mengalami kemajuan pesat. Sejak awal tahun 2018 telah berlaku Standar Akuntansi untuk Entitas Mikro Kecil dan Menengah (SAK EMKM) yang sangat sederhana dan diharapkan EMKM mampu melakukan 
pencatatan dan pelaporan sederhana berbentuk Neraca dan Laporan Laba Rugi. Kegiatan pengabdian masyarakat ini difokuskan pada usaha foto copy yang ada di sekitar kampus STIE Perbanas Surabaya. Kegiatan pengabdian masyarakat pada usaha foto copy tersebut menunjukkan bahwa (a) pemilik sudah memiliki pemahaman akuntansi dan pajak secara sederhana, (b) pemilik dengan cepat mampu mengoperasikan software aplikasi akuntansi dan pajak sederhana karena saat pemilik melakukan entri transaksi langsung dapat diketahui pelaporannya tanpa berpikir lagi, (c) software ini masih perlu dipertimbangkan pengembangannya ketika nanti omzet usaha foto copy ini meningkat ataupun ketika unit bisnis usaha mereka mulai beraneka ragam.

\section{DAFTAR PUSTAKA}

Fess, W. (2017). Pengantar Akuntansi Adaptasi Indonesia (Edisi 4). Jakarta: Salemba Empat.

IAI. (2016). SAK Entitas Mikro, Kecil dan Menengah. Jakarta.

Jati Hironnymus, B. B. (2004). Menumbuhkan Kebiasaan Usaha Kecil Menyusun Laporan Keuangan. Jurnal Bisnis Dan Usahawan, 2(2), 210-218.

RI. (2013). Peraturan Pemerintah Republik Indonesia Nomor 46 Tahun 2013 Tentang Pajak Penghasilan Orang Pribadi Usaha Kecil.

Supriyati \& Wulanditya. (2012). The SME Perception Toward The Accounting Standard Without Public Accountability (SAK ETAP) and Self Assessment System For Increasing Voluntary Tax Compliance. International Journal of Business and Management, 4. 